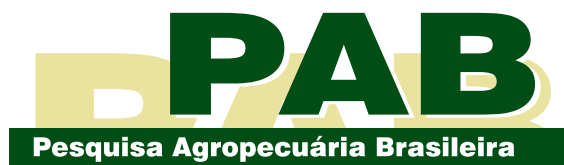

ISSN 1678-3921

Journal homepage: www.embrapa.br/pab

For manuscript submission and journal contents, access: www.scielo.br/pab

\title{
Silicate rocks as an alternative potassium fertilizer for upland rice and common bean crops
}

\begin{abstract}
The objective of this work was to evaluate the efficiency of molten and ground alkaline potassium-silicate rocks (K1) and of ground phonolite rock (K2) as sources of potassium for upland rice (Oryza sativa) and common bean (Phaseolus vulgaris) crops, in comparison with the traditional source $(\mathrm{KCl})$. Two experiments - one with each crop - were conducted on a Typic Haplorthox in a randomized complete block design with four replicates. The treatments consisted of three sources $(\mathrm{KCl}, \mathrm{K} 1$, and $\mathrm{K} 2)$ and four rates $(0,20$, 40 , and $80 \mathrm{~kg} \mathrm{ha}^{-1} \mathrm{~K}_{2} \mathrm{O}$ ) of $\mathrm{K}$. Regardless of the used source, $\mathrm{K}$ fertilization increased the leaf $\mathrm{K}$ content and grain yield of the upland rice and common bean crops. The agronomic efficiency index (AEI) of the alternative K sources varied according to the crop. For upland rice, the AEI of K2 was $8 \%$ higher than that of $\mathrm{KCl}$ at the recommended $\mathrm{K}$ rate, but similar at the highest rate. For common bean, the AEI values of $\mathrm{K} 1$ were close to that of $\mathrm{KCl}$ at the rates of 40 and $80 \mathrm{~kg} \mathrm{ha}^{-1} \mathrm{~K}_{2} \mathrm{O}$. The alternative sources $\mathrm{K} 1$ and $\mathrm{K} 2$ supply $\mathrm{K}$ and increase the grain yield of common bean and upland rice, respectively, similarly to $\mathrm{KCl}$.
\end{abstract}

Index terms: Oryza sativa, Phaseolus vulgaris, ground phonolite, in-furrow fertilization, potassium fertilization.

\section{Rochas silicáticas como fertilizante potássico para as culturas do arroz de terras altas e feijão comum}

Resumo - O objetivo deste trabalho foi avaliar a eficiência de rochas potássio-silicáticas alcalinas fundidas e moídas (K1) e de rocha fonolito moída (K2) como fontes de potássio para as culturas do arroz de terras altas (Oryza sativa) e do feijão comum (Phaseolus vulgaris), em comparação à fonte tradicional $(\mathrm{KCl})$. Dois experimentos - um com cada cultura - foram conduzidos em Latossolo Vermelho argiloso, tendo-se utilizado delineamento de blocos ao acaso com quatro repetições. Os tratamentos consistiram de três fontes $\left(\mathrm{KCl}, \mathrm{K} 1\right.$ e K2) e quatro doses $\left(0,20,40\right.$ e $80 \mathrm{~kg} \mathrm{ha}^{-1}$ de $\left.\mathrm{K}_{2} \mathrm{O}\right)$ de $\mathrm{K}$. Independentemente da fonte utilizada, a adubação potássica incrementou o teor foliar de $\mathrm{K}$ e a produtividade de grãos das culturas do arroz de terras altas e do feijão comum. O índice de eficiência agronômica (IEA) das fontes alternativas de $\mathrm{K}$ variou de acordo com a cultura. Para o arroz de terras altas, o IEA do $\mathrm{K} 2$ foi $8 \%$ mais alto que o do $\mathrm{KCl}$ na dose de $\mathrm{K}$ recomendada, mas semelhante na maior dose. Para o feijão, os valores do IEA do K1 foram próximos ao do $\mathrm{KCl}$ nas doses de 40 e $80 \mathrm{~kg} \mathrm{ha}^{-1} \mathrm{de}_{2} \mathrm{O}$. As fontes alternativas $\mathrm{K} 1$ e K2 fornecem K e aumentam a produtividade de grãos do feijão comum e do arroz de terras altas, respectivamente, de forma semelhante ao $\mathrm{KCl}$.

Termos para indexação: Oryza sativa, Phaseolus vulgaris, fonolito moído, fertilização no sulco, adubação potássica. 


\section{Introduction}

Rice (Oryza sativa L.) and common bean (Phaseolus vulgaris L.) are two widely cultivated crops in Brazil; however, the average yields of both of them have been considered low, being approximately 2,400 and $1,500 \mathrm{~kg} \mathrm{ha}^{-1}$, respectively (Acompanhamento..., 2020). Inadequate crop management practices and cultivation in regions with irregular rainfall and in soils poor in nutrients are among the main factors that contribute to low yields, and the use of fertilizers stands out as having the greatest effect on crop yields (Soratto et al., 2013; Carvalho et al., 2018).

Among the essential nutrients for those two crops, potassium is the most taken up by upland rice and the second taken up by common bean, just below nitrogen (Soratto et al., 2013; Crusciol et al., 2016). That element is related to enzyme activation, photoassimilate transport in the phloem, and grain formation and maturation, which make grains heavier and bulkier (Marschner, 2012).

In agriculture, the main $\mathrm{K}$ fertilizer used is potassium chloride $(\mathrm{KCl})$. In Brazil, the demand for $\mathrm{K}$ in the sector reached 4.1 $\mathrm{Tg} \mathrm{K}$ in 2013, whereas its production was only of $0.280 \mathrm{Tg} \mathrm{K}$, classifying the country as a major importer of $\mathrm{KCl}$, with a trade value of US\$3.3 billion, indicating a need to explore alternative K sources (Mancuso et al., 2014; Manning, 2018; Sipert et al., 2020).

To have potential for use in agriculture, a mineral should present a high nutrient content, as well as bioavailability (Teixeira et al., 2015; Manning, 2018; Ciceri et al., 2019). Studies on the feasibility of rock powders as agricultural sources of $\mathrm{K}$ have been carried out since the 1970s and 1980s, and the sources were applied either in natura (Lopes et al., 1972; Eichler \& Lopes, 1983; Ribeiro et al., 2010; Martins et al., 2015; Manning, 2018) or after some kind of solubilization process (Santos et al., 2016; Ciceri et al., 2017, 2019).

In Brazil, the steady increase in agricultural production and its dependence on the import of $\mathrm{K}$ fertilizers over long distances justify assessing rocks as K sources for agricultural use (Manning, 2018). An example of a mineral source with potential for use in agriculture is the phonolite rock (Mancuso et al., 2014; Martins et al., 2015; Teixeira et al., 2015), a silicate rock of volcanic origin, with $7-8 \%(\mathrm{w} / \mathrm{w}) \mathrm{K}_{2} \mathrm{O}$, whose main constituents are alkaline feldspar and feldspathoids (Teixeira et al., 2012, 2015; Tavares et al., 2018). Due to the high level of alkaline oxides, this rock is widely used as a flux by the ceramic industries (Andrade et al., 2005). In addition to $\mathrm{K}$, phonolite contains other elements, such as silicon, calcium, magnesium, and iron (Teixeira et al., 2012, 2015; Martins et al., 2015), which are also required by plants. Therefore, finely ground phonolite rock can also be used in agriculture, especially to supply K to plants (Mancuso et al., 2014; Martins et al., 2015; Tavares et al., 2018). Some studies have also shown that thermal treatments, such as calcination or melting, can increase the available $\mathrm{K}$ in alkaline silicate rocks (Duarte et al., 2015; Martins et al., 2015; Teixeira et al., 2015; Santos et al., 2016; Ciceri et al., 2019). Moreover, these Cl-free sources may be interesting options for organic agriculture, where $\mathrm{KCl}$ is not allowed (Ciceri et al., 2017). However, the obtained results are still inconclusive (Mancuso et al., 2014; Duarte et al., 2015; Martins et al., 2015; Boldrin et al., 2019; Ciceri et al., 2019) and experiments under field conditions continue scarce.

The objective of this work was to evaluate the efficiency of molten and ground alkaline K-silicate rocks (K1) and of ground phonolite rock (K2) as sources of $\mathrm{K}$ for upland rice and common bean, in comparison with the traditional source $(\mathrm{KCl})$.

\section{Materials and Methods}

Two field experiments - one with common bean and one with upland rice - were conducted during the $2007 / 2008$ crop year, in the municipality of Botucatu, in the state of São Paulo, Brazil (22 $51^{\prime} \mathrm{S}, 48^{\circ} 26^{\prime} \mathrm{W}$, at an altitude of $740 \mathrm{~m}$ ). According to Köppen's classification, the predominant climate in the region is Cwa. The climatic data recorded during the experimental period are shown in Figure 1.

The soil was classified as a clay-textured Latossolo Vermelho distroférrico, i.e., a Typic Haplorthox (Santos et al., 2018). The experimental area was managed in the no-tillage system, and topsoil $(0.00-0.20 \mathrm{~m})$ samples collected before crop sowing were subjected to chemical characterization (Raij et al., 2001). The soil of the area used for the common bean experiment showed: $4.8 \mathrm{pH}\left(\mathrm{CaCl}_{2}\right) ; 23 \mathrm{~g} \mathrm{dm}^{-3}$ organic matter; $19 \mathrm{mg} \mathrm{dm}^{-3} \mathrm{P}_{\text {resin }} ; 1.4,24,13$, and $55 \mathrm{mmol}_{\mathrm{c}} \mathrm{dm}^{-3}$ exchangeable $\mathrm{K}, \mathrm{Ca}, \mathrm{Mg}$, and $\mathrm{H}+\mathrm{Al}$, respectively; and base saturation (BS) of $41 \%$. The soil of the area for the experiment with rice showed: $4.2 \mathrm{pH}\left(\mathrm{CaCl}_{2}\right) ; 18 \mathrm{~g} \mathrm{dm}^{-3}$ organic matter; $3.6 \mathrm{mg} \mathrm{dm}^{-3} \mathrm{P}_{\text {resinin }} ; 1.2,22$, 9, and 32 $\mathrm{mmol}_{\mathrm{c}} \mathrm{dm}^{-3}$ exchangeable $\mathrm{K}, \mathrm{Ca}, \mathrm{Mg}$, and $\mathrm{H}+\mathrm{Al}$, 
respectively; and BS of 50\%. The soils used for both experiments contained low exchangeable $\mathrm{K}$ levels, as well as a $\mathrm{pH}$ and BS considered low for the studied crops (Raij et al., 1997); despite the last two values being low, liming was not done, since the areas were managed under a no-tillage system and superficial liming would have had a low or no effect until crop establishment. This is in alignment with Ribeiro et al. (2010), who did not find any influence of soil acidity amendment on $\mathrm{K}$ release from silicate rocks.

Both experiments were arranged in a randomized complete block design, with four replicates. The treatments consisted of three sources and of four rates of $\mathrm{K}$. The used sources were: $\mathrm{KCl}$, standard source $\left(58 \% \mathrm{~K}_{2} \mathrm{O}\right) ; \mathrm{K} 1, \mathrm{~K}$ fertilizer made from molten and ground alkaline $\mathrm{K}$-silicate rocks, containing $11.0 \%$ $\mathrm{K}_{2} \mathrm{O}, 51.7 \% \mathrm{SiO}_{2}, 16.8 \% \mathrm{CaO}, 0.18 \% \mathrm{P}_{2} \mathrm{O}_{5}, 16 \% \mathrm{Al}_{2} \mathrm{O}_{3}$, and $0.38 \% \mathrm{Na}_{2} \mathrm{O}$; and $\mathrm{K} 2$, ground in natura phonolite rock, containing $8.42 \% \mathrm{~K}_{2} \mathrm{O}, 52.5 \% \mathrm{SiO}_{2}, 1.58 \% \mathrm{CaO}$, $0.05 \% \mathrm{P}_{2} \mathrm{O}_{5}, 20.7 \% \mathrm{Al}_{2} \mathrm{O}_{3}$, and $7.53 \% \mathrm{Na}_{2} \mathrm{O}$. The four applied rates were: $0,20,40$, and $80 \mathrm{~kg} \mathrm{ha}^{-1} \mathrm{~K}_{2} \mathrm{O}$, equivalent to $0,1 / 2,1$, and 2 times the recommended $\mathrm{K}_{2} \mathrm{O}$ rates for the common bean and upland rice crops (Raij et al., 1997). Therefore, the rates of each source were: $34.5,69$, and $138 \mathrm{~kg} \mathrm{ha}^{-1} \mathrm{KCl} ; 182,364$, and $728 \mathrm{~kg} \mathrm{ha}^{-1} \mathrm{~K} 1$; and 237.5, 475, and $950 \mathrm{~kg} \mathrm{ha}^{-1} \mathrm{~K} 2$. The $\mathrm{K} 1$ source was produced by melting alkaline $\mathrm{K}$ silicate rocks at $1,500^{\circ} \mathrm{C}$, with further fine grinding after being cooled, whereas K2 was produced by fine grinding the phonolite rock; both passed completely (100\%) through a $0.074 \mathrm{~mm}$ sieve (ABNT, 1997). The two alternative

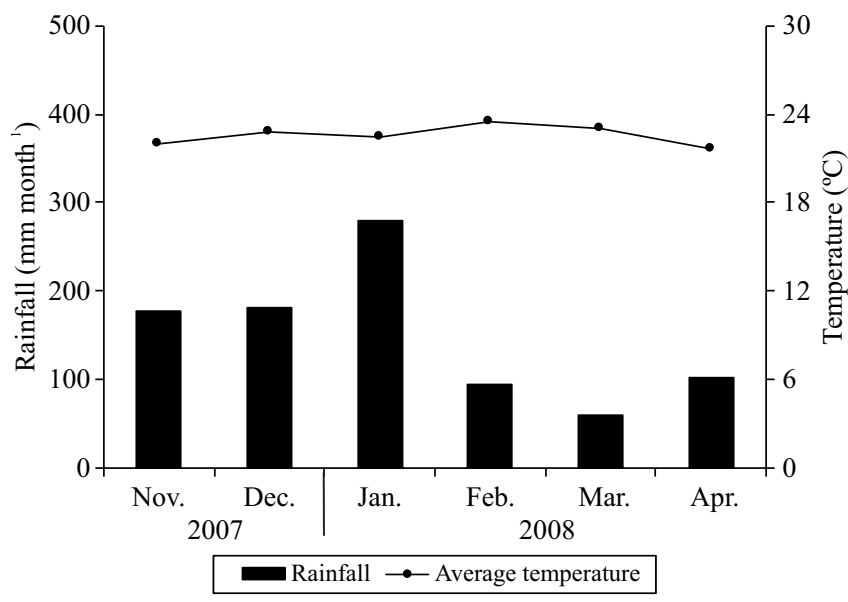

Figure 1. Monthly rainfall and average temperature in the experimental area from November to April of the 2007/2008 growing season.
$\mathrm{K}$ sources were obtained in the municipality of Poços de Caldas, in the state of Minas Gerais, Brazil. Each experimental plot consisted of six rows with $5.0 \mathrm{~m}$ of length. The four central rows were considered as the useful area for the evaluations, excluding $0.5 \mathrm{~m}$ at the end of each row.

The IAC 202 upland rice cultivar was sown on $11 / 15 / 2007$, with a spacing of $0.45 \mathrm{~m}$, using 70 seed per meter, and $10 \mathrm{~kg} \mathrm{ha}^{-1} \mathrm{~N}$ (urea) and $80 \mathrm{~kg} \mathrm{ha}^{-1} \mathrm{P}_{2} \mathrm{O}_{5}$ (single superphosphate) were applied in the sowing furrow, plus $40 \mathrm{~kg} \mathrm{ha}^{-1} \mathrm{~N}$ as topdressing in the tillering stage. The Pérola common bean cultivar was sown on $1 / 14 / 2008$, with a spacing of $0.45 \mathrm{~m}$, using 15 seed per square meter, and $10 \mathrm{~kg} \mathrm{ha}^{-1} \mathrm{~N}$ (urea) and $30 \mathrm{~kg} \mathrm{ha}^{-1} \mathrm{P}_{2} \mathrm{O}_{5}$ (single superphosphate) were applied in the sowing furrow, plus $70 \mathrm{~kg} \mathrm{ha}^{-1} \mathrm{~N}$ as topdressing in the $\mathrm{V}_{4}$ stage. For both crops, fertilization with $\mathrm{N}$ and/or $\mathrm{P}$, in the sowing furrow and/or as topdressing, followed the recommendations of Raij et al. (1997). Crop sowing and fertilizer distribution in the planting furrow were performed mechanically with a tractor-driven multiple no-tillage seeder. The $\mathrm{K}$ treatments were manually applied three days after plant emergence, in a continuous fillet on soil surface, $5 \mathrm{~cm}$ from the plant rows.

In both crops, diagnostic leaves were sampled according to Raij et al. (1997) and leaf K and Si concentration were evaluated (Malavolta et al., 1997; Korndörfer et al., 2004). Harvests were performed on 4/27/2008 for common bean and on 3/27/2008 for rice. Yield components were assessed for eight plants of common bean and for one $2 \mathrm{~m}$ long row of upland rice per plot on the eve of the harvest. Grain yields $\left(\mathrm{kg} \mathrm{ha}^{-1}\right)$ were determined in two $3 \mathrm{~m}$ long rows per plot. The data for 100-grain weight and grain yield were corrected for a water content of $13 \mathrm{~g} \mathrm{~kg}^{-1}$ on a wet basis.

Data for each crop were separately subjected to the analysis of variance. The $\mathrm{K}$ source means were compared by the t-test (least significant difference), at $5 \%$ probability. The SISVAR statistical software package (Ferreira, 2011) was used. The K rate effects were evaluated by the regression analysis using the PROC MIXED procedure of SAS (SAS Institute Inc., Cary, NC, USA). Regardless of whether an interaction occurred between the sources and rates of the $\mathrm{K}$ fertilizer, relative yield was considered as the ratio between the yield of each treatment and the control 
(without $\mathrm{K}$ application). The agronomic efficiency index (AEI) was calculated as the percentage ratio between yields resulting from the $\mathrm{K}$ sources applied at the same rate. The crop yield obtained in the control was subtracted from the other two yields, as follows: AEI $(\%)=[(\mathrm{Y} 2-\mathrm{Y} 1) /(\mathrm{Y} 3-\mathrm{Y} 1)] \times 100$, where $\mathrm{Y} 1$ is the crop yield in the control treatment without $\mathrm{K}$ application, Y2 is the crop yield with an alternative $\mathrm{K}$ source ( $\mathrm{K} 1$ or $\mathrm{K} 2)$ at the corresponding rate, and $\mathrm{Y} 3$ is the crop yield with the traditional $\mathrm{K}$ source $(\mathrm{KCl})$ at the corresponding rate; the average of 12 control plots was used to determined Y1.

\section{Results and Discussion}

Leaf $\mathrm{K}$ concentrations in both crops were affected by the studied factors and their interaction (Table 1). For upland rice, the leaf $\mathrm{K}$ concentration was always higher when $\mathrm{KCl}$ was used, followed by $\mathrm{K} 2$ and $\mathrm{K} 1$, with quadratic responses to the $\mathrm{K}$ rates (Figure $2 \mathrm{~A}$ ). The maximum leaf $\mathrm{K}$ concentrations were reached at the rates of 68,56 , and $54 \mathrm{~kg} \mathrm{ha}^{-1} \mathrm{~K}_{2} \mathrm{O}$, applied as $\mathrm{KCl}, \mathrm{K} 2$, and $\mathrm{K} 1$, respectively. For common bean, there was an increase in leaf $\mathrm{K}$ concentration with the applied $\mathrm{K}$ rates, which was more significant when $\mathrm{K} 1$ and $\mathrm{KCl}$ were used (Figure $3 \mathrm{~A}$ ). At the recommended rate $\left(40 \mathrm{~kg} \mathrm{ha}^{-1} \mathrm{~K}_{2} \mathrm{O}\right), \mathrm{KCl}$ and $\mathrm{K} 1$ provided higher concentrations of the nutrient, whereas at two times the recommended rate $\left(80 \mathrm{~kg} \mathrm{ha}^{-1} \mathrm{~K}_{2} \mathrm{O}\right)$, the leaf $\mathrm{K}$ concentration was highest when $\mathrm{K} 1$ was used. On this topic, Teixeira et al. (2015) suggested that melting at temperatures above $1,200^{\circ} \mathrm{C}$ modifies the structure of the original mineral and should facilitate the release of the $\mathrm{K}^{+}$ion, which was bound to the structure of the minerals that constitute the rock. According to Duarte et al. (2015) and Santos et al. (2016), the calcination of silicate rocks with limestone or $\mathrm{CaCl}_{2}$ at high temperatures increases the solubility of their minerals. In a pot experiment, Martins et al. (2015) found that the calcined phonolite provided a higher soil exchangeable $\mathrm{K}$ content; however, higher $\mathrm{K}$ concentrations in the leaves of 'Marandu' grass (Brachiaria brizantha Stapf) were obtained with the application of ground in natura phonolite rock. In the present study, despite the variation in leaf $\mathrm{K}$ concentration (Figures $2 \mathrm{~A}$ and $3 \mathrm{~A}$ ), on average, all sources provided values within the recommended range for the evaluated crops, varying from $20-24 \mathrm{~g} \mathrm{~kg}^{-1}$ for common bean and $13-$ $30 \mathrm{~g} \mathrm{~kg}^{-1}$ for upland rice (Raij et al., 1997), while the control treatment (without $\mathrm{K}$ application) resulted in leaf $\mathrm{K}$ concentrations below the recommended ranges.

Table 1. Leaf potassium concentration, yield components, and grain yield of upland rice (Oryza sativa) and common bean (Phaseolus vulgaris) crops as affected by sources and rates of a $\mathrm{K}$ fertilizer ${ }^{(1)}$.

\begin{tabular}{|c|c|c|c|c|c|c|c|}
\hline \multirow[t]{2}{*}{ Variable } & \multicolumn{3}{|c|}{ K source } & \multicolumn{3}{|c|}{ Source of variation $(\mathrm{p}<\mathrm{F})$} & \multirow{2}{*}{$\begin{array}{l}\mathrm{CV} \\
(\%)\end{array}$} \\
\hline & $\mathrm{K} 1^{(2)}$ & $\mathrm{K} 2^{(3)}$ & $\mathrm{KCl}$ & Source (S) & Rate (R) & $\mathrm{S} \times \mathrm{R}$ & \\
\hline & \multicolumn{7}{|c|}{ Upland rice } \\
\hline Leaf $\mathrm{K}$ concentration $\left(\mathrm{g} \mathrm{kg}^{-1}\right)$ & 15.0 & 17.5 & 20.8 & $<0.001$ & $<0.001$ & $<0.001$ & 8.4 \\
\hline Leaf Si concentration $\left(\mathrm{g} \mathrm{kg}^{-1}\right)$ & 15.4 & 16.6 & 16.6 & 0.051 & 0.001 & 0.004 & 9.8 \\
\hline Number of panicles per $\mathrm{m}^{2}$ & 120.9 & 127.3 & 129.4 & 0.273 & 0.014 & 0.009 & 12.1 \\
\hline Number of spikelets per panicle & $133.8 \mathrm{a}$ & $146.5 \mathrm{a}$ & $140.9 \mathrm{a}$ & 0.227 & 0.006 & 0.698 & 14.6 \\
\hline Spikelet fertility (\%) & $58.5 \mathrm{a}$ & $63.3 \mathrm{a}$ & $60.7 \mathrm{a}$ & 0.217 & 0.145 & 0.110 & 12.5 \\
\hline 1,000-grain weight (g) & 21.8 & 21.9 & 21.9 & 0.649 & $<0.001$ & 0.024 & 2.5 \\
\hline \multirow[t]{2}{*}{ Grain yield $\left(\mathrm{kg} \mathrm{ha}^{-1}\right)$} & 1,508 & 1,581 & 1,682 & 0.008 & $<0.001$ & 0.001 & 9.4 \\
\hline & \multicolumn{7}{|c|}{ Common bean } \\
\hline Leaf $\mathrm{K}$ concentration $\left(\mathrm{g} \mathrm{kg}^{-1}\right)$ & 23.1 & 20.0 & 22.6 & $<0.001$ & $<0.001$ & 0.005 & 7.2 \\
\hline Leaf Si concentration $\left(\mathrm{g} \mathrm{kg}^{-1}\right)$ & 2.9 & 3.1 & 4.1 & $<0.001$ & $<0.001$ & $<0.001$ & 12.8 \\
\hline Final plant population (plants per $\mathrm{m}^{2}$ ) & $25.2 \mathrm{a}$ & $25.1 \mathrm{a}$ & $25.0 \mathrm{a}$ & 0.459 & 0.398 & 0.678 & 13.4 \\
\hline Number of pods per plant & 7.0 & 6.9 & 6.9 & 0.914 & 0.073 & 0.008 & 10.0 \\
\hline Number of grains per pod & 4.5 & 4.5 & 5.1 & $<0.001$ & 0.255 & 0.024 & 8.8 \\
\hline 100-grain weight (g) & $30.4 \mathrm{ab}$ & $30.0 \mathrm{~b}$ & $31.6 \mathrm{a}$ & 0.039 & $<0.001$ & 0.410 & 5.9 \\
\hline Grain yield $\left(\mathrm{kg} \mathrm{ha}^{-1}\right)$ & 2,002 & 1,903 & 1,982 & 0.036 & $<0.001$ & 0.024 & 5.6 \\
\hline
\end{tabular}

${ }^{(1)}$ Means followed by equal letters, in the rows, do not differ by the least significant difference test, at $5 \%$ probability. ${ }^{(2)}$ Molten and ground alkaline K-silicate rocks. ${ }^{(3)}$ Ground phonolite rock. 
The leaf $\mathrm{Si}$ concentration was affected by the $\mathrm{K}$ source $\times$ rate interaction in both crops (Table 1). For upland rice, the leaf Si concentration was higher with the use of the $\mathrm{KCl}$ source at the recommended $\mathrm{K}$ rate
(40 $\mathrm{kg} \mathrm{ha}^{-1} \mathrm{~K}_{2} \mathrm{O}$ ), whereas $\mathrm{K} 1$ and $\mathrm{K} 2$ did not differ from each other (Figure $2 \mathrm{~B}$ ). However, at the highest $\mathrm{K}$ rate, $\mathrm{K} 2$ provided a higher $\mathrm{Si}$ concentration than the other sources. When $\mathrm{KCl}$ was used, no significant
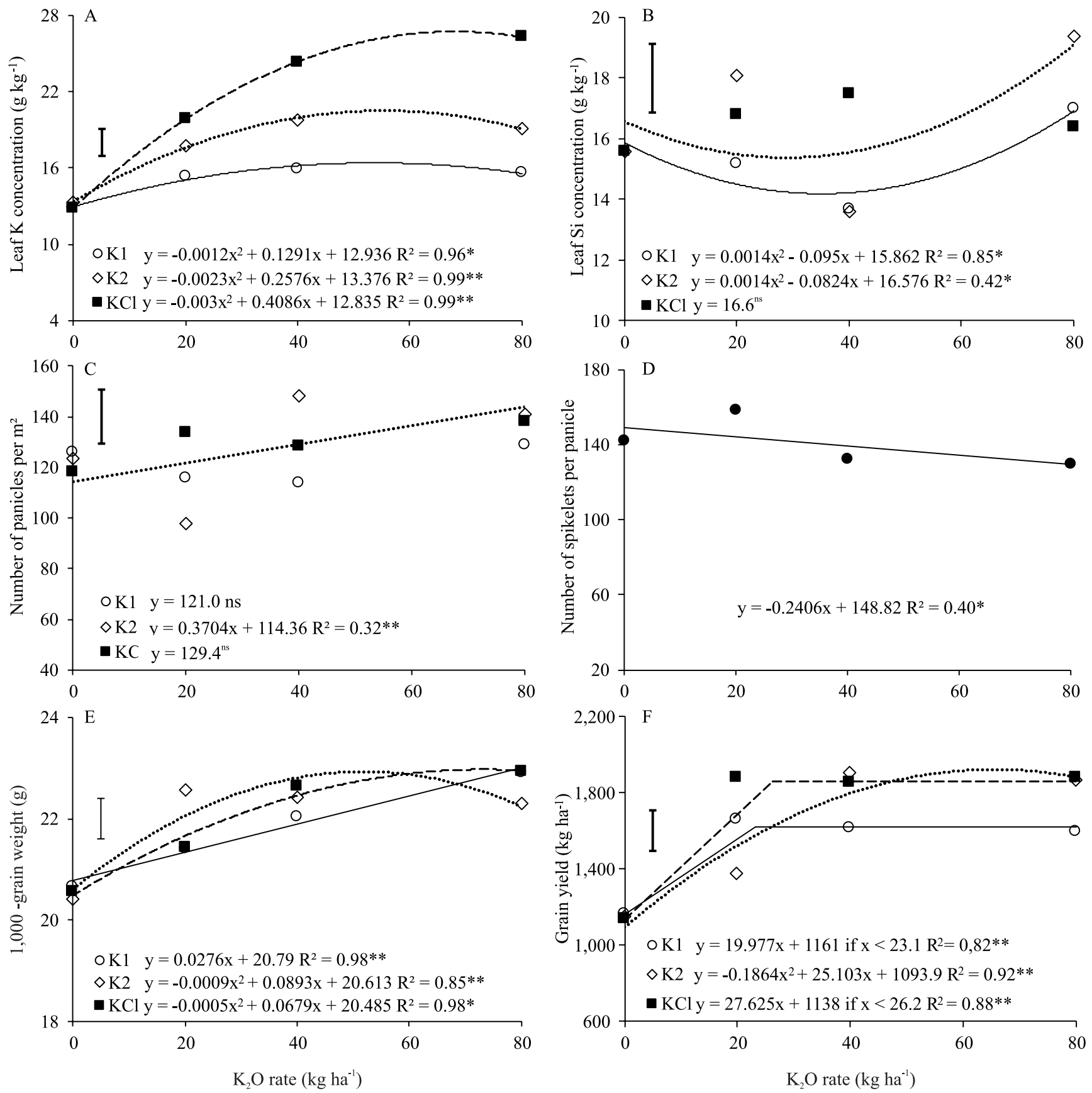

Figure 2. Effect of sources and rates of potassium on leaf K concentration (A), leaf Si concentration (B), number of spikelets per panicle $(C)$, number of panicles per square meter (D), 1,000-grain weight $(E)$, and grain yield $(\mathrm{F})$ of the upland rice (Oryza sativa) crop. Black circles represent the average of three K sources. K1, molten and ground alkaline K-silicate rocks; and $\mathrm{K} 2$, ground phonolite rock. * and **Significant by the t-test, at 5 and $1 \%$ probability, respectively. Vertical bars indicate the least significant difference (LSD) to separate K sources in a same K rate by the LSD test, also at 5\% probability. 
variation occurred in the $\mathrm{Si}$ concentration in rice leaves as a function of the applied rates. For common bean, the leaf Si concentration increased quadratically with the use of $\mathrm{KCl}$ and linearly with that of $\mathrm{K} 1$ and
$\mathrm{K} 2$ (Figure $3 \mathrm{~B}$ ). At the rates of 20 and $40 \mathrm{~kg} \mathrm{ha}^{-1} \mathrm{~K}_{2} \mathrm{O}$, the leaf $\mathrm{Si}$ concentration using $\mathrm{KCl}$ was higher than that with the other sources. These results indicate that, although large amounts of $\mathrm{Si}$ were applied through
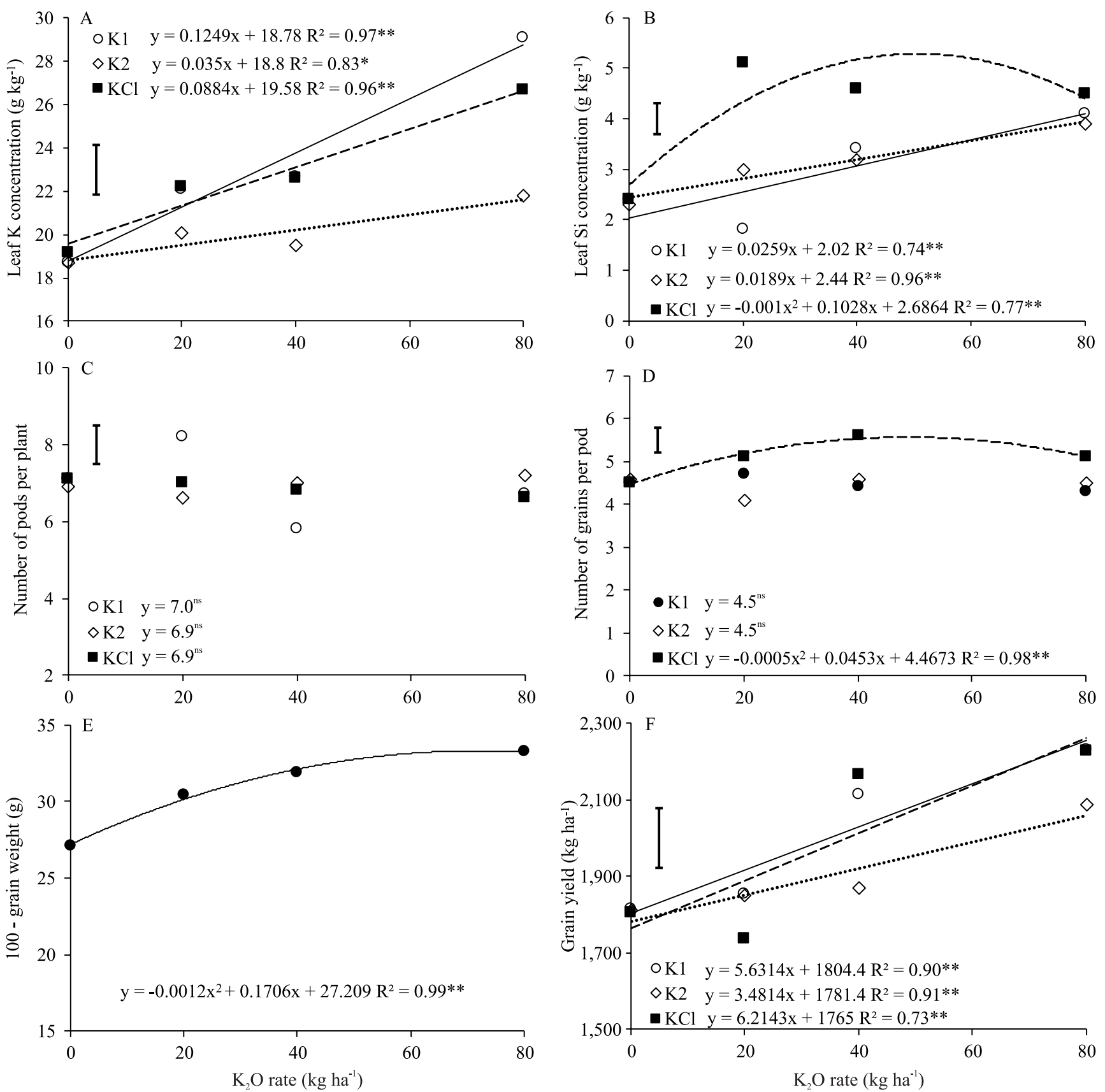

Figure 3. Effect of sources and rates of potassium on leaf $\mathrm{K}$ concentration (A), leaf Si concentration (B), number of pods per plant (C), number of grains per pod (D), 100-grain weight (E), and grain yield (F) of the common bean (Phaseolus vulgaris) crop. Black circles represent the average of three K sources. K1, molten and ground alkaline K-silicate rocks; and $\mathrm{K} 2$, ground phonolite rock. * and **Significant by the t-test, at 5 and $1 \%$ probability, respectively. Vertical bars indicate the least significant difference (LSD) to separate K sources in a same K rate by the LSD test, also at $5 \%$ probability. 
the $\mathrm{K} 1$ and $\mathrm{K} 2$ sources, this element was not readily available for the crops. The soluble/available $\mathrm{Si}$ in the soil may have been sufficient to supply the plants, without the need of Si application via fertilizer.

For upland rice, there was a significant interaction between $\mathrm{K}$ sources and rates for the number of panicles per square meter and 1,000-grain weight (Table 1). The $\mathrm{K}$ rates increased linearly the number of panicles per square meter only when $\mathrm{KCl}$ was used (Figure $2 \mathrm{C}$ ). At the rate of $20 \mathrm{~kg} \mathrm{ha}^{-1} \mathrm{~K}_{2} \mathrm{O}, \mathrm{KCl}$ resulted in a higher number of panicles per square meter than $\mathrm{K} 2$, which resulted in the highest value at the recommended $\mathrm{K}$ rate of $40 \mathrm{~kg} \mathrm{ha}^{-1} \mathrm{~K}_{2} \mathrm{O}$, differing from $\mathrm{K} 1$. The number of spikelets per panicle decreased linearly with increasing $\mathrm{K}$ rates, regardless of the used source (Table 1 and Figure 2 D). Contrarily, spikelet fertility was not affected by the studied factors (Table 1). For 1,000-grain weight, there an increase as a function of $\mathrm{K}$ rates for all sources, with a quadratic response for $\mathrm{K} 2$ and $\mathrm{KCl}$ and a linear one for $\mathrm{K} 1$ (Figure $2 \mathrm{E}$ ). At the rate of $20 \mathrm{~kg} \mathrm{ha}^{-1} \mathrm{~K}_{2} \mathrm{O}$, a difference was observed among sources, with the greatest 1,000-grain weight being obtained with the application of K2.

For common bean, the final plant population was not affected by the assessed factors, and the mean value was 25.1 plants per square meter (Table 1). The number of pods per plant and the number of grains per pod, however, were influenced by the $\mathrm{K}$ source $\times$ rate interaction. At the rate of $20 \mathrm{~kg} \mathrm{ha}^{-1} \mathrm{~K}_{2} \mathrm{O}, \mathrm{K} 1$ provided a higher number of pods per plant, whereas, at the recommended rate of $40 \mathrm{~kg} \mathrm{ha}^{-1} \mathrm{~K}_{2} \mathrm{O}$, the highest values were obtained with $\mathrm{K} 2$ and $\mathrm{KCl}$ (Figure $3 \mathrm{C}$ ). However, no change was observed in the number of pods per plant as a function of the applied $\mathrm{K}$ rate. Regarding the number of grains per pod, the $\mathrm{KCl}$ rates provided a quadratic increase up to an estimated rate of $45 \mathrm{~kg} \mathrm{ha}^{-1} \mathrm{~K}_{2} \mathrm{O}$ (Figure $3 \mathrm{D}$ ). At the recommended $\mathrm{K}$ rate, $\mathrm{KCl}$ resulted in a higher number of grains per pod, compared with the alternative sources $\mathrm{K} 1$ and $\mathrm{K} 2$. In addition, the 100-grain weight varied according to the $\mathrm{K}$ sources and rates, but without any significant interaction (Table 1). This parameter was higher with the use of $\mathrm{KCl}$, compared with $\mathrm{K} 2$, but did not differ statistically from the value obtained with $\mathrm{K} 1$. Regardless of the source, the $\mathrm{K}$ rates quadratically increased the 100-grain weight of common bean up to an estimated rate of $71 \mathrm{~kg} \mathrm{ha}^{-1} \mathrm{~K}_{2} \mathrm{O}$ (Figure $3 \mathrm{E}$ ).
The grain yields of both crops were affected by the studied factors and their interaction (Table 1). For upland rice, grain yield fitted a quadratic equation with a maximum predicted value for $\mathrm{K} 2$ at the rate of $67 \mathrm{~kg} \mathrm{ha}^{-1} \mathrm{~K}_{2} \mathrm{O}$, increasing with $\mathrm{K} 1$ and $\mathrm{KCl}$ only up to the estimated rates of 23.1 and $26.2 \mathrm{~kg} \mathrm{ha}^{-1} \mathrm{~K}_{2} \mathrm{O}$, respectively (Figure $2 \mathrm{~F}$ ). At the rate of $20 \mathrm{~kg} \mathrm{ha}^{-1} \mathrm{~K}_{2} \mathrm{O}$, $\mathrm{KCl}$ provided a higher grain yield than $\mathrm{K} 2$; however, at the rates of 40 and $80 \mathrm{~kg} \mathrm{ha}^{-1} \mathrm{~K}_{2} \mathrm{O}, \mathrm{KCl}$ and $\mathrm{K} 2$ provided similar grain yields, which were higher than that of K1. Considering the recommended $\mathrm{K}$ rate, the AEI of K2 was $8 \%$ higher than that of $\mathrm{KCl}$; however, at the rate of $20 \mathrm{~kg} \mathrm{ha}^{-1} \mathrm{~K}_{2} \mathrm{O}$, the AEI of $\mathrm{K} 2$ was lower than that of $\mathrm{KCl}$, showing similar values at the highest $\mathrm{K}$ rate (Table 2 ). For K1, the AEI values were lower, corresponding to approximately $60 \%$ of the one obtained for $\mathrm{KCl}$. Compared with the control (without $\mathrm{K}$ application), the $\mathrm{K}$ rates using $\mathrm{KCl}$ increased rice yield, without differing from each other and similarly to the highest $\mathrm{K} 2$ rates at 40 and $80 \mathrm{~kg} \mathrm{ha}^{-1} \mathrm{~K}_{2} \mathrm{O}$. Even though the leaf $\mathrm{K}$ concentrations were within the recommended range, the maximum rice yield was obtained using a lower rate than that required to achieve the maximum leaf $\mathrm{K}$ concentration with the application of $\mathrm{KCl}$ (Figure $2 \mathrm{~A}$ and $\mathrm{F}$ ). A possible explanation is that, because of the $\mathrm{K}$ uptake mechanisms, plants uptake quantities above their metabolic needs, causing these extra amounts to accumulate in plant cell organelles, characterizing luxury consumption (Marschner, 2012). According to Santos et al. (2016), although the K from soluble fertilizers is more readily available to plants, negative effects on plant growth and yield may occur when the dissolution of $\mathrm{KCl}$ is fast, leading to a rapid increase - beyond the optimum range - in the concentration of $\mathrm{K}$ in the soil solution. Therefore, a slow-release or a slightly water-soluble fertilizer would be advantageous, as indicated by the results for leaf $\mathrm{K}$ concentration and grain yield of the upland rice crop with the application of the highest $\mathrm{K} 2$ rates (Figures $2 \mathrm{~A}$ and $\mathrm{F}$ ).

For common bean, regardless of the used source, the increasing $\mathrm{K}$ rates linearly increased grain yield, with steeper increases when $\mathrm{K} 1$ and $\mathrm{KCl}$ were applied (Figure $3 \mathrm{~F}$ ). A significant difference between the studied sources was observed only at the recommended rate of $\mathrm{K}_{2} \mathrm{O}$, with $\mathrm{K} 1$ and $\mathrm{KCl}$ promoting higher grain yields than $\mathrm{K} 2$. The increase in grain yield in relation to the control treatment only became expressive after the application of $40 \mathrm{~kg} \mathrm{ha}^{-1} \mathrm{~K}_{2} \mathrm{O}$. The $\mathrm{K} 1$ source 
provided AEI values of 85 and $98 \%$ relative to that of $\mathrm{KCl}$, at the 40 and $80 \mathrm{~kg} \mathrm{ha}^{-1} \mathrm{~K}_{2} \mathrm{O}$ rates, respectively (Table 2). However, K2 exhibited a low AEI, which was only 18 and $65 \%$ in relation to that of $\mathrm{KCl}$ at the 40 and $80 \mathrm{~kg} \mathrm{ha}^{-1} \mathrm{~K}_{2} \mathrm{O}$ rates, respectively.

In both crops, increases occurred in leaf $\mathrm{K}$ concentration, yield components, and grain yield (Figures 2 and 3) as a function of $\mathrm{K}$ fertilizer rates, regardless of the used source. Significant correlations were also observed between leaf $\mathrm{K}$ concentration and grain yield for both common bean $(r=0.51 ; p=0.0002)$ and upland rice $(\mathrm{r}=0.68 ; \mathrm{p}<0.0001)$. This result could be explained by the direct and indirect participation of $\mathrm{K}$ in many process, from photosynthesis to the activation of approximately 60 enzymatic systems (Malavolta et al., 1997; Marschner, 2012). The leaf K concentration and grain yield results (Figures $2 \mathrm{~A}$ and $\mathrm{F}$ and $3 \mathrm{~A}$ and $\mathrm{F}$ ) are indicative that upland rice responded more quickly to the $\mathrm{K}$ fertilizer than common bean, which may require a highly soluble source such as $\mathrm{KCl}$. This finding may be related to the fact that grasses have a lower cation exchange capacity in their roots, when compared with legumes. Therefore, grasses are more efficient in the removal of monovalent cations, such as $\mathrm{K}^{+}$, because there is less competition for binding sites in the soil (Marschner, 2012). Moreover, grasses take up more $\mathrm{K}$ because of the greater root length to shoot dry matter ratio, and the plants have different abilities to use K physiologically (Samal et al., 2010).

According to the obtained results, K-silicate agrominerals show potential for agricultural use, as $\mathrm{K} 1$ and $\mathrm{K} 2$ supplied $\mathrm{K}$ and increased the grain yield of the common bean and upland rice crops, respectively, in a way similar to $\mathrm{KCl}$, the traditional source (Figures $2 \mathrm{~F}$ and $3 \mathrm{~F}$, and Table 2). Manning (2018) concluded that the weathering of K silicates, mediated by soil microbial communities, occurs sufficiently quickly to provide nutrients to growing plants, whereas silicate minerals have a particular role to play as fertilizers of tropical Oxisols, which are typically developed through the weathering of parent silicate rocks and deep leaching of their bases. In addition, Martins et al. (2015) and Tavares et al. (2018) found that the application of ground phonolite rock resulted in significant increments of exchangeable $\mathrm{K}$ and soluble $\mathrm{Si}$ in the soil. Silicon is important as it can: help mitigate stress, such as that caused by aluminum toxicity in root growth (Giongo \& Bohnen, 2011); improve the use of other elements, including P (Castro \& Crusciol, 2013); and increase disease resistance in

Table 2. Increased and relative yields of the common bean (Phaseolus vulgaris) and upland rice (Oryza sativa) crops as affected by sources and rates of a potassium fertilizer, as well as the agronomic efficiency index (AEI) of three rates of two alternative K sources - molten and ground alkaline K-silicate rocks (K1) and ground phonolite rock (K2) -, compared with the traditional source $(\mathrm{KCl})$.

\begin{tabular}{|c|c|c|c|c|c|c|c|c|}
\hline \multirow{2}{*}{$\begin{array}{l}\mathrm{K}_{2} \mathrm{O} \text { rate } \\
\left(\mathrm{kg} \mathrm{ha}^{-1}\right)\end{array}$} & \multicolumn{3}{|c|}{ Increased yield $\left(\mathrm{kg} \mathrm{ha}^{-1}\right)^{(1)}$} & \multicolumn{3}{|c|}{ Relative yield $(\%)^{(2)}$} & \multicolumn{2}{|c|}{ AEI $(\%)^{(3)}$} \\
\hline & $\mathrm{K} 1$ & $\mathrm{~K} 2$ & $\mathrm{KCl}$ & $\mathrm{K} 1$ & $\mathrm{~K} 2$ & $\mathrm{KCl}$ & K1 & $\mathrm{K} 2$ \\
\hline & \multicolumn{8}{|c|}{ Upland rice } \\
\hline 0 & - & - & - & 100 & 100 & 100 & - & - \\
\hline 20 & 501 & 229 & 748 & 143 & 120 & 165 & 68 & 30 \\
\hline 40 & 456 & 760 & 706 & 139 & 166 & 161 & 66 & 108 \\
\hline 80 & 433 & 743 & 755 & 137 & 165 & 166 & 59 & 98 \\
\hline \multirow[t]{2}{*}{ Mean } & - & - & - & - & - & - & 64 & 79 \\
\hline & \multicolumn{8}{|c|}{ Common bean } \\
\hline 0 & - & - & - & 100 & 100 & 100 & - & - \\
\hline 20 & 40 & 39 & - & 102 & 102 & 97 & (4) & (4) \\
\hline 40 & 300 & 59 & 373 & 117 & 103 & 121 & 85 & 18 \\
\hline 80 & 418 & 278 & 448 & 123 & 115 & 125 & 98 & 65 \\
\hline Mean & - & - & - & - & - & - & 92 & 42 \\
\hline
\end{tabular}


plants (Guntzer et al., 2012; Savvas \& Ntatsi, 2015). Therefore, although there was no consistent increase in leaf $\mathrm{Si}$ concentrations in the present study (Figures 2 $\mathrm{B}$ and $3 \mathrm{~B}$ ), the continuous use of Si-rich sources can benefit crops, especially in tropical conditions, since highly weathered soils have low plant-available $\mathrm{Si}$ (Barbosa Filho et al., 2001). Furthermore, the Si taken up by crops usually is not replaced in the form of fertilizer, unlike other nutrients.

Based on the obtained results, multielement agrominerals such as K-silicate rocks, besides occurring widely in Brazil, may be alternatives to $\mathrm{KCl}$, with positive results in the supply of $\mathrm{K}$ to grain crops. However, for a better use of the alternative K sources, the following factors should be taken into account: $\mathrm{Na}_{2} \mathrm{O}$ levels in $\mathrm{K} 2$ (7.53\%), energy expenditure in the K1 melting process, and high logistics costs of both sources due to their low $\mathrm{K}$ concentrations, which may limit their use only to locations relatively close to their production sites. Despite these challenges, according to Santos et al. (2016), increases in the price of soluble $\mathrm{K}$ sources may encourage investments in the development of $\mathrm{K}$ fertilizer sources from silicate rocks, making them viable for a broader use.

\section{Conclusions}

1. Potassium fertilization, regardless of the used source, increases the leaf $\mathrm{K}$ concentration and grain yield of the upland rice (Orzya sativa) and common bean (Phaseolus vulgaris) crops.

2. The agronomic efficiencies of the evaluated alternative $\mathrm{K}$ sources - molten and ground alkaline K-silicate rocks and ground phonolite rock - vary according to the crop.

3. The alternative $\mathrm{K}$ sources supply $\mathrm{K}$ and increase the grain yield of common bean and upland rice, respectively, similarly to $\mathrm{KCl}$, the traditional source.

\section{Acknowledgments}

To Conselho Nacional de Desenvolvimento Científico e Tecnológico (CNPq), for providing an award for excellence in research to the first and second authors; and to Dr. Maria Márcia Pereira Sartori, for helping to adjust the equations.

\section{References}

ABNT. Associação Brasileira de Normas Técnicas. NBR NM-ISO 2395: peneiras de ensaio e ensaio de peneiramento: vocabulário. Rio de Janeiro, 1997. 9p.

ACOMPANHAMENTO DA SAFRA BRASILEIRA [DE] GRÃOS: safra 2019/2020: décimo segundo levantamento, v.7, n.12, set. 2020. Available at: <http://www.conab.gov.br>. Accessed on: Oct. 12020.

ANDRADE, P.M.; NETO, H.S.N.; MONTEIRO, S.N.; VIEIRA, C.M.F. Efeito da adição de fonolito na sinterização de argila caulinítica. Cerâmica, v.51, p.361-370, 2005. DOI: https://doi.org/10.1590/S0366-69132005000400010.

BARBOSA FILHO, M.P.; SNYDER, G.H.; FAGERIA, N.K.; DATNOFF, L.E.; SILVA, O.F. Silicato de cálcio como fonte de silício para o arroz de sequeiro. Revista Brasileira de Ciência do Solo, v.25, p.325-330, 2001. DOI: https://doi.org/10.1590/S010006832001000200009 .

BOLDRIN, P.F.; SOUTO, H.F.; SALLES, L.S.; FURTINI NETO, A.E. Alternative sources of potassium for maize cultivation. Ciência e Agrotecnologia, v.43, e023619, 2019. DOI: https://doi.org/10.1590/1413-7054201943023619.

CARVALHO, M. da C.S.; NASCENTE, A.S.; FERREIRA, G.B.; MUTADIUA, C.A.P.; DENARDIN, J.E. Phosphorus and potassium fertilization increase common bean grain yield in Mozambique. Revista Brasileira de Engenharia Agrícola e Ambiental, v.22, p.308-314, 2018. DOI: https://doi.org/10.1590/1807-1929/agriambi.v22n5p308-314.

CASTRO, G.S.A.; CRUSCIOL, C.A.C. Effects of superficial liming and silicate application on soil fertility and crop yield under rotation. Geoderma, v.195-196, p.234-242, 2013. DOI: https://doi.org/10.1016/j.geoderma.2012.12.006.

CICERI, D.; CLOSE, T.C.; BARKER, A.V.; ALLANORE, A. Fertilizing properties of potassium feldspar altered hydrothermally. Communications in Soil Science and Plant Analysis, v.50, p.482-491, 2019. DOI: https://doi.org/10.1080/001 03624.2019.1566922.

CICERI, D.; OLIVEIRA M. de; ALLANORE, A. Potassium fertilizer via hydrothermal alteration of K-feldspar ore. Green Chemistry, v.19, p.5187-5202, 2017. DOI: https://doi.org/10.1039/ C7GC02633A.

CRUSCIOL, C.A.C.; FERNANDES, A.M.; CARMEIS FILHO, A.C. de A.; ALVAREZ, R. de C.F. Macronutrient uptake and removal by upland rice cultivars with different plant architecture. Revista Brasileira de Ciência do Solo, v.40, e0150115, 2016. DOI: https://doi.org/10.1590/18069657rbcs20150115.

DUARTE, I.N.; SOUSA, R.T.X. de; KORNDÖRFER, G.H.; PEREIRA, H.S. Alternative potash fertilizer source for millet crop. Journal of Plant Nutrition, v.38, p.1961-1972, 2015. DOI: https://doi.org/10.1080/01904167.2015.1009097.

EICHLER, V.; LOPES, A.S. Disponibilidade do potássio do verdete de Abaeté, calcinado com e sem calcário magnesiano, para a cultura do milho (Zea mays L.), em solo de textura argilosa. Ciência e Prática, v.7, p.136-146, 1983. 
FERREIRA, D.F. Sisvar: a computer statistical analysis system. Ciência e Agrotecnologia, v.35, p.1039-1042, 2011. DOI: https://doi.org/10.1590/S1413-70542011000600001.

GIONGO, V.; BOHNEN, H. Relação entre alumínio e silício em genótipos de milho resistente e sensível a toxidez de alumínio. Bioscience Journal, v.27, p.348-356, 2011.

GUNTZER, F.; KELLER, C.; MEUNIER, J.-D. Benefits of plant silicon for crops: a review. Agronomy for Sustainable Development, v.32, p.201-213, 2012. DOI: https://doi.org/10.1007/ s13593-011-0039-8.

KORNDÖRFER, G.H.; PEREIRA, H.S.; NOLLA, A. Análise de silício: solo, planta e fertilizante. 2.ed. Uberlândia: UFU, 2004. 34p. (Boletim técnico, 2).

LOPES, A.S.; FREIRE, J.C.; AQUINO, L.H.; FELIPE, M.P. Contribuição ao estudo da rocha potássica - Verdete de Abaeté (Glauconita) para fins agrícolas. Agros, v.2, p.32-42, 1972.

MALAVOLTA, E.; VITTI, G.C.; OLIVEIRA, S.A. de. Avaliação do estado nutricional das plantas: princípios e aplicações. 2.ed. Piracicaba: Potafos, 1997. 319p.

MANCUSO, M.A.C.; SORATTO, R.P.; CRUSCIOL, C.A.C.; CASTRO, G.S.A. Effect of potassium sources and rates on Arabica coffee yield, nutrition and macronutrient export. Revista Brasileira de Ciência do Solo, v.38, p.1448-1456, 2014. DOI: https://doi.org/10.1590/S0100-06832014000500010.

MANNING, D.A.C. Innovation in resourcing geological materials as crop nutrients. Natural Resources Research, v.27, p.217-227, 2018. DOI: https://doi.org/10.1007/s11053-017-9347-2.

MARSCHNER, P. Marschner's mineral nutrition of higher plants. $3^{\text {rd }}$ ed. London: Elsevier, 2012. 643p.

MARTINS, V.; GUELFI SILVA, D.R.; MARCHI, G.; LEITE, M.C.A.; MARTINS, É. de S.; GONÇALVES, A.S.F.; GUILHERME, L.R.G. Effect of alternative multinutrient sources on soil chemical properties. Revista Brasileira de Ciência do Solo, v.39, p.194-204, 2015. DOI: https://doi.org/10.1590/01000683rbcs20150587.

RAIJ, B. van; ANDRADE, J.C. de; CANTARELLA, H.; QUAGGIO, J.A. (Ed.). Análise química para avaliação da fertilidade de solos tropicais. Campinas: IAC, 2001. 284p.

RAIJ, B. van; CANTARELLA, H.; QUAGGIO, J.A.; FURLANI, A.M.C. (Ed.). Recomendações de adubação e calagem para o Estado de São Paulo. 2.ed. rev. e atual. Campinas: IAC, 1997. 285p. (Boletim técnico, 100).

RIBEIRO, L. da S.; SANTOS, A.R. dos; SOUZA, L.F. da S.; SOUZA, J.S. Rochas silicáticas portadoras de potássio como fontes do nutriente para as plantas solo. Revista Brasileira de Ciência do Solo, v.34, p.891-897, 2010. DOI: https://doi.org/10.1590/S0100-06832010000300030.

SAMAL, D.; KOVAR, J.L.; STEINGROBE, B.; SADANA, U.S.; BHADORIA, P.S.; CLAASSEN, N. Potassium uptake efficiency and dynamics in the rhizosphere of maize (Zea mays L.), wheat (Triticum aestivum L.), and sugar beet (Beta vulgaris L.) evaluated with a mechanistic model. Plant and Soil, v.332, p.105-121, 2010. DOI: https://doi.org/10.1007/s11104-009-0277-6.

SANTOS, H.G. dos; JACOMINE, P.K.T.; ANJOS, L.H.C. dos; OLIVEIRA, V.Á. de; LUMBRERAS, J.F.; COELHO, M.R.; ALMEIDA, J.A. de; ARAÚJO FILHO, J.C. de; OLIVEIRA, J.B. de; CUNHA, T.J.F. Sistema brasileiro de classificação dos solos. 5.ed. rev. e ampl. Brasília: Embrapa, 2018. 356p.

SANTOS, W.O.; MATTIELO, E.M.; VERGUTZ, L.; COSTA, R.F. Production and evaluation of potassium fertilizers from silicate rock. Journal of Plant Nutrition and Soil Science, v.179, p.547-556, 2016. DOI: https://doi.org/10.1002/jpln.201500484.

SAVVAS, D.; NTATSI, G. Biostimulant activity of silicon in horticulture. Scientia Horticulturae, v.196, p.66-81, 2015. DOI: https://doi.org/10.1016/j.scienta.2015.09.010.

SIPERT, S.; COHIM, E.; NASCIMENTO, F.R.A. do. Identification and quantification of main anthropogenic stocks and flows of potassium in Brazil. Environmental Science and Pollution Research, v.27, p.32579-32593, 2020. DOI: https://doi.org/10.1007/s11356-020-09526-1.

SORATTO, R.P.; FERNANDES, A.M.; SANTOS, L.A. dos; JOB, A.L.G. Nutrient extraction and exportation by common bean cultivars under different fertilization levels: I - Macronutrients. Revista Brasileira de Ciência do Solo, v.37, p.1027-1042, 2013. DOI: https://doi.org/10.1590/S0100-06832013000400020.

TAVARES, L. de F.; CARVALHO, A.M.X. de; CAMARGO, L.G.B.; PEREIRA, S.G. de F.; CARDOSO, I.M. Nutrients release from powder phonolite mediated by bioweathering actions. International Journal of Recycling of Organic Waste in Agriculture, v.7, p.89-98, 2018. DOI: https://doi.org/10.1007/ s40093-018-0194-x.

TEIXEIRA, A.M.S.; GARRIDO, F.M.S.; MEDEIROS, M.E.; SAMPAIO, J.A. Estudo do comportamento térmico da rocha fonolito com fins à produção de fertilizantes. Holos, ano31, p.5264, 2015. DOI: https://doi.org/10.15628/holos.2015.1825.

TEIXEIRA, A.M.S.; SAMPAIO, J.A.; GARRIDO, F.M.S.; MEDEIROS, M.E. Avaliação da rocha fonolito como fertilizante alternativo de potássio. Holos, ano28, p.21-33, 2012. DOI: https://doi.org/10.15628/holos.2012.1102. 